\title{
SELECTED ASPECTS OF THE LOW LEVEL AUTOMATIC TAXI CONTROL SYSTEM CONCEPT
}

\author{
Albert Zajdel ", Cezary Szczepański", Mariusz KrawczyK", Jerzy Graffstein*, \\ Piotr MASLOWSKI" \\ *Instytut Lotnictwa (Institute of Aviation), al. Krakowska 110/114, 02-256 Warszawa \\ albert.zajdel@ilot.edu.pl, cezary.szczepanski@ilot.edu.pl, mariusz.krawczyk@ilot.edu.pl, jerzy.graffstein@ilot.edu.pl, \\ piotr.maslowski@ilot.edu.pl
}

\begin{abstract}
Taxiing of manned and remotely piloted aircraft is still performed by pilots without using a system of automatic control of direction and speed. Several reasons have emerged in recent years that make the automation of taxiing an important design challenge. The reasons are: decreased airport capacity due to the growing number of aircraft, poor ground operation conditions during poor visibility conditions, an increase in workload of pilots and air traffic controllers and the integration of simultaneous ground operations of manned and remotely piloted air vehicles. This paper presents selected aspects of the concept of a Low Level Automatic Taxi Control System. In particular, it emphasizes the means of controlling an aircraft during taxiing, accuracy requirements of the system and proposes control techniques. The resulting controller of the system is adaptable for different aircrafts. The actuators and their mechanical connections to available controls are the aircraft specific part and are designed for the particular type - in this case - a general aviation light airplane.
\end{abstract}

Keywords: taxi, taxiing, automatic taxi, taxi control system.

\section{INTRODUCTION}

The taxi phase of the ground operations of aircrafts has not been automated yet. Today, the existing airport visual aids and air traffic controllers (ATC) voice guidance is inefficient when facing the challenges of a growing number of aircrafts at the airports, simultaneous operations of manned and unmanned air vehicles and low visibility conditions. The Eurocontrol forecasts that the number of instrumental flight rules (IFR) operation will grow by $16 \%$ between 2015 and 2022 [1]. Dense airport traffic causes losses to the aircraft operators because of the fuel cost and the maintenance cost of the engine, tires and breaks due to longer taxiing time. In years 2005-2014 taxiing was the second phase in which accidents were most likely to occur [2]. In fact, the biggest disaster in the aviation history happened during ground operations of two airplanes at Tenerife airport [3]. 
It is expected that in the future the workload of the pilots and the ATC will rise with increasing traffic. Consequently, automation of taxiing will be necessary to assure the required level of safety, limit the human-operators workload and improve the taxiing costs. The Automatic Taxi Control System (ATCS) consists of the trajectory generation module and the low level airplane control system. Low level control is the generation of signals for the actuators according to the control law by transforming signals from sensors, so the airplane is tracking the desired path. This paper presents the concept of Low Level Automatic Taxi Control System (LLATCS) with a generic taxi control algorithm tested on a general aviation light airplane.

\section{STATE OF THE ART}

Apart from classical taxiing aids like ATC voice commands, "Follow-Me" cars, marshalling and Airport Moving Maps (AMM) are the most recent electronic support for pilots [4]. AMMs display an electronic airport map with aircraft current positions. More advanced AMMs also have warning functions. Various versions of AMMs from producers like Garmin, Thales, Honeywell, Lufthansa and Jeppesen are certified for general aviation and passenger aircraft. Other types of taxiing support involve external tug vehicles controlled by the pilot $[5,6]$. Nevertheless, those solutions only have a supporting function for the pilot. Three ATCS programs exist. Enhancement of an airport capacity by reducing taxiing time was the goal of the SOAR project conducted by NASA and Optimal Synthesis [7]. Presented solutions focused on the higher level of airport guidance, that is the taxiing time for large passenger aircraft - in that case - the Boeing 737 [8]. The authors presented simulation results of a non-linear aircraft taxi controller designed with a feedback linearization technique. The model for the control system synthesis was simplified. It treated the aircraft as a point mass model without an aerodynamic effect. The actuators were modelled by first order inertia modules. The simulations were conducted on the Boeing 737 model that included models of landing gear suspension and tires. The results were rewarding with the mean cross-track error at $0.16 \mathrm{~m}$. The University of Malta worked on simulations of automatic taxiing during the ALICIA project in the Seventh European Union Framework Programme [9, 10]. It addressed large passenger aircraft and the simulations were conducted on an Airbus A320 model. The aircraft model was simplified to a two-dimensional bicycle model that moved without slip. The design used the fuzzy logic regulator for the front wheel steering and proportional controllers for thrust and brakes. The controller was tested in the X-plane environment proving stable taxiing with path steering errors below $0.2 \mathrm{~m}$. The third system is being developed through the ERA project financed by European Defence Agency and is intended for remotely piloted aircraft systems [11]. The first two systems have been developed for passenger aircraft which creates many organizational difficulties that go beyond the simulations and conduct the real aircraft tests. The connection between the actuators and the aircraft controls, which are complex systems in those types of aircraft, are not taken into account. Furthermore, the designs do not specify the sensor requirements and their errors, for example, it is only assumed that the accurate navigation is available [10]. The concept presented in this paper includes both the sensor requirements and the analysis of the mechanical connections between aircraft controls and actuators. The aircraft specific part of the LLATCS addresses general aviation light aircraft so the real tests can be conducted with less effort after the simulation phase. 


\section{WORKING CONDITIONS AND AREAS OF APPLICATION}

The LLATCS controls the aircraft only during the taxi phase. The formulated definition of this phase states that, when the aircraft is at a parking position, the taxi starts when the engine is running within its operational limits and after a clearance for taxiing has been granted from the ATC. It ends when the aircraft is ready for take-off on the runway. When the aircraft is landing, the taxi starts after deceleration and finishes at a full stop at a parking position.

\subsection{Means of control of the aircraft during taxiing}

To follow a solid ground taxiway ordered by the ATC the aircraft must be able to change its heading and speed allowing also full stops. When the nose wheel is connected directly (e.g. the Piper Arrow) or by spring tubes (e.g. the Cessna 172) to the steering mean, usually rudder pedals, the heading is controlled by its deflection. In this case, if the rudder is coupled with the pedals directly, it also deflects opposite to the nose wheel. If the nose wheel is a castor type, not connected to steering, the only way to control the heading below the speed of a rudder authority is differential breaking of the main wheels. In practice, operators prefer when brakes are used at a minimum level in order to limit the wear of brakes and tires to minimize the airplane exploitation costs. Depending on the force necessary to operate the controls, it is done directly via geared linkage and pushrods system or by actuators. The speed during taxiing is controlled by the thrust and braking forces. Thrust is generated by the engine driven propeller or the jet engine itself. Thrust reversers are not used during taxi operations. Aircraft brakes have different designs and they all share the disc or the drum and the cylinder part which exerts pressure on them. They are operated hydraulically or pneumatically by the levers on the rudder pedals, a control yoke or an instrument panel. The number of disks starts from one for the lightest aircrafts (e.g. the Czajka MP-02). Usually, only the main wheels are braked. In some designs, using the left and the right brake separately allows turning.. It is assumed that the speed of taxing is sufficiently low to neglect the effects of aerodynamic control surfaces other than rudder [8].

\subsection{Types of aircrafts addressed by the system}

The designed control algorithm of the aircraft during taxi is generic and can be adapted to different types of aircraft. By generic we assume that only a change in configuration variables in the software will be needed for a specific aircraft installation. The aircraft specific part, which are actuators and their mechanical connections, must be designed for a specific aircraft or groups of aircraft that share similar design solutions. This part addresses all light (MTOW $<5,700 \mathrm{~kg}$ ) fixed wing aircrafts capable of self-propelled taxiing on solid ground. The early design simulations and tests are going to be conducted on the Czajka MP-02 ultralight airplane. Such a choice will allow of an easier organization of tests on real aircraft in the next phases of the design process. 


\subsection{System operating limits during taxiing}

Tab. 1 presents the operating limits for aircraft during taxiing. The maximum ground speed is an average value for taxi presented in [12]. The maximum crosswind speed correlates with the maximum value allowed for take-off of the Cessna 172. Surface type and surface condition are crucial in determining physical characteristics of the wheels interacting with the ground.

Tab. 1. General system operating limits [Zajdel, 2016]

\begin{tabular}{|l|c|}
\hline Ground speed & $0-36[\mathrm{~km} / \mathrm{h}]$ \\
\hline Cross wind & $28[\mathrm{~km} / \mathrm{h}]$ \\
\hline Surface conditions & Dry, Wet \\
\hline Surface type & Concrete, Asphalt \\
\hline Temperatures & $-40 \div 60\left[{ }^{\circ} \mathrm{C}\right]$ \\
\hline Visibility & All conditions \\
\hline Weather & All conditions \\
\hline
\end{tabular}

\section{ATCS FUNCTIONAL REQUIREMENTS}

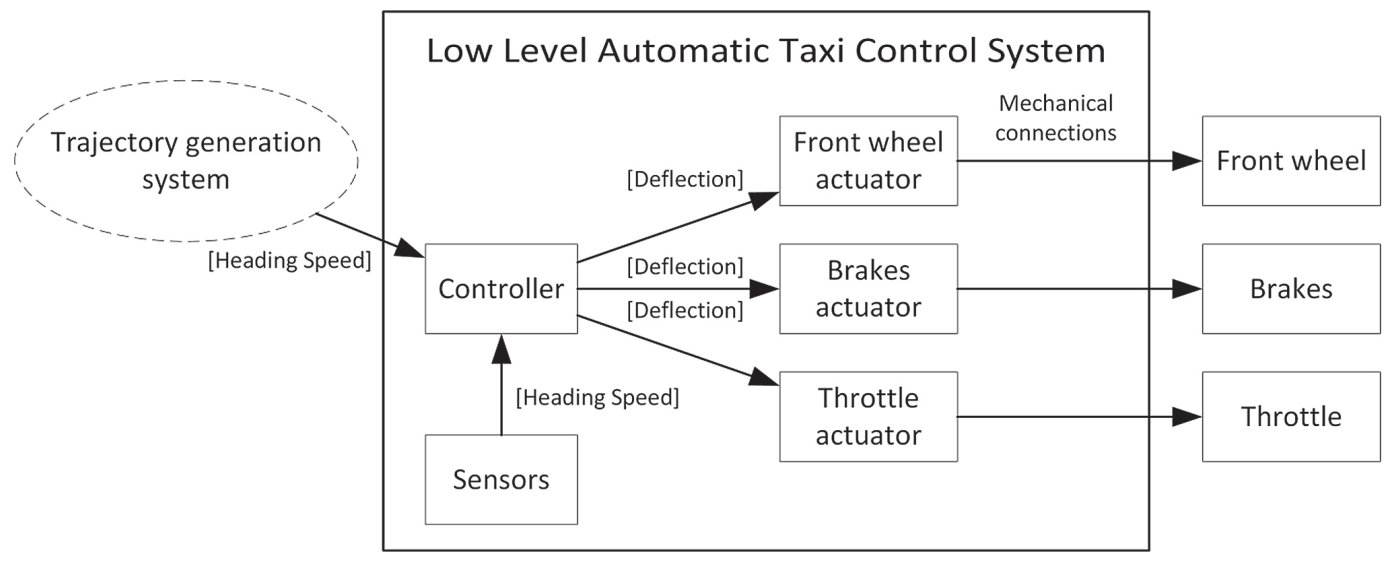

Fig. 1. General ATCS structure [Zajdel, 2016]

\subsection{General ATCS structure}

Fig. 1 shows the ATCS general structure. The controller block is a generic taxiing control algorithm. It can be a separate electronic device or a software module in an appropriate aircraft avionics system, usually Flight Management System (FMS). Controller uses several avionic data 
buses for the input and output of the data. The available interfaces are: CANbus, ARINC-429, MIL-1553 and RS-232/485. Inputs in the form of desired heading and speed are obtained from the trajectory generation system. The system has its own sensors and is independent from instruments available on aircraft. The controller computes and sends deflection commands to the three actuators which are mechanically connected to the aircraft controls: the front wheel, the throttle lever, and the brake lever. The actuators and their mechanical connections must be chosen and installed for a specific aircraft system or groups of aircraft sharing the same solutions because of their many different designs.

\subsection{Actuation methods of selected aircraft controls}

The control of the ground speed requires operation of the engine, propeller and brake system. The most popular form of engine control in general aviation are linkage systems that use bowdens for actuation of the engine elements. The amount of available engine control variables differs depending on the engine type. Throttle levers exist in every design and control the engine power by regulating the mass flow rate of air (in fuel-injected engines) or air to fuel mixture (in carbureted engines) delivered to the cylinders. The amount of fuel added to the intake airflow is regulated by the mixture lever. In some engines it is done automatically (e.g. Rotax engines), therefore it is not present in the cockpit. There are also some new general aviation aircraft models equipped with Full Authority Digital Engine Controller (FADEC) e.g. the Liberty XL2 and the Diamond DA42. FADEC allows of a single lever operation to control the engine overall power "by wire". Aircrafts with FADEC are out of scope of the early designs of the LLATCS. Other engine controls include, depending on the engine type: the choke lever, the air intake lever and the fuel valve which are stationary during taxiing. Although, some pilots lean the mixture during taxiing it will not be a function of the system. The LLATCS is designed for bowden operated engine controls and regulates the engine power by changing the throttle position.

Brake force is controlled by pressing the breaks on the top of the rudder pedals, a handle at the yoke or on the instrument panel (e.g. DynAero MCR). In the simplest brake system, the controls are directly connected with the piston in the cylinder which generates hydraulic pressure that moves the jaws in the wheels. They clamp on the disc or expand the drum to dissipate rolling wheel energy into friction. More complex systems on bigger aircrafts include hydraulic pumps and boosters.

Designs of the front wheel steering include direct connection between rudder pedals and the front wheel (e.g. the Piper Arrow) or connection by spring tubes (e.g. the Cessna 172). Direct connection uses linkages or pushrods. When spring tubes are present, pressing one of the rudder pedals on the ground initially compresses the spring that in turn deflects the nose wheel. Typically, if the aircraft is stopped on dry pavement, the springs cannot cause much movement to the wheel. Once the aircraft is moving, the resistance is lower and the steering force increases smoothly as it compresses the spring. Friction forces between the rotating front wheel and the ground, when the aircraft is stationary, exceeds the pilot's legs capabilities. Therefore, steering the front wheel should be performed when the aircraft has started to move. 


\subsection{Accuracy requirements}

The total ATCS position error must fall between sufficiently low limits to allow using taxiways and to avoid collisions. The ATCS errors can be defined in the same way as in the works concerning the trajectory tracking maneuvers in flight $[13,14]$. They are the deviations of the airplane center of gravity position from the closest point on the desired path in a two dimensional coordinate system related to that point on the path, where the $\mathrm{x}$ axis is tangent to the path. The two components of that error are the cross-track in the y direction and the longitudinal error in the $\mathrm{x}$ direction. The total system cross-track error (TSCTE) can be divided into the path steering error, the path definition error and the navigation system error Fig. 2 [14]. The trajectory generation block contributes to the path definition error (PDE). The navigation system error (NSE) is the result of the AHRS and other sensors inaccuracies. The controller block with actuators contributes to the path steering error (PSE). Only the path steering error and navigation system error are in the scope of the project. The total system cross-track error can be written in the form of a mean square error [10] shown in equation (1)

$$
T S C T E=\sqrt{\frac{P D E^{2}+P S E^{2}+N S E^{2}}{3}}
$$

where: TSCTE - Total System Cross Track Error, PDE - Path Definition Error, PSE - Path Steering Error, NSE - Navigation System Error.

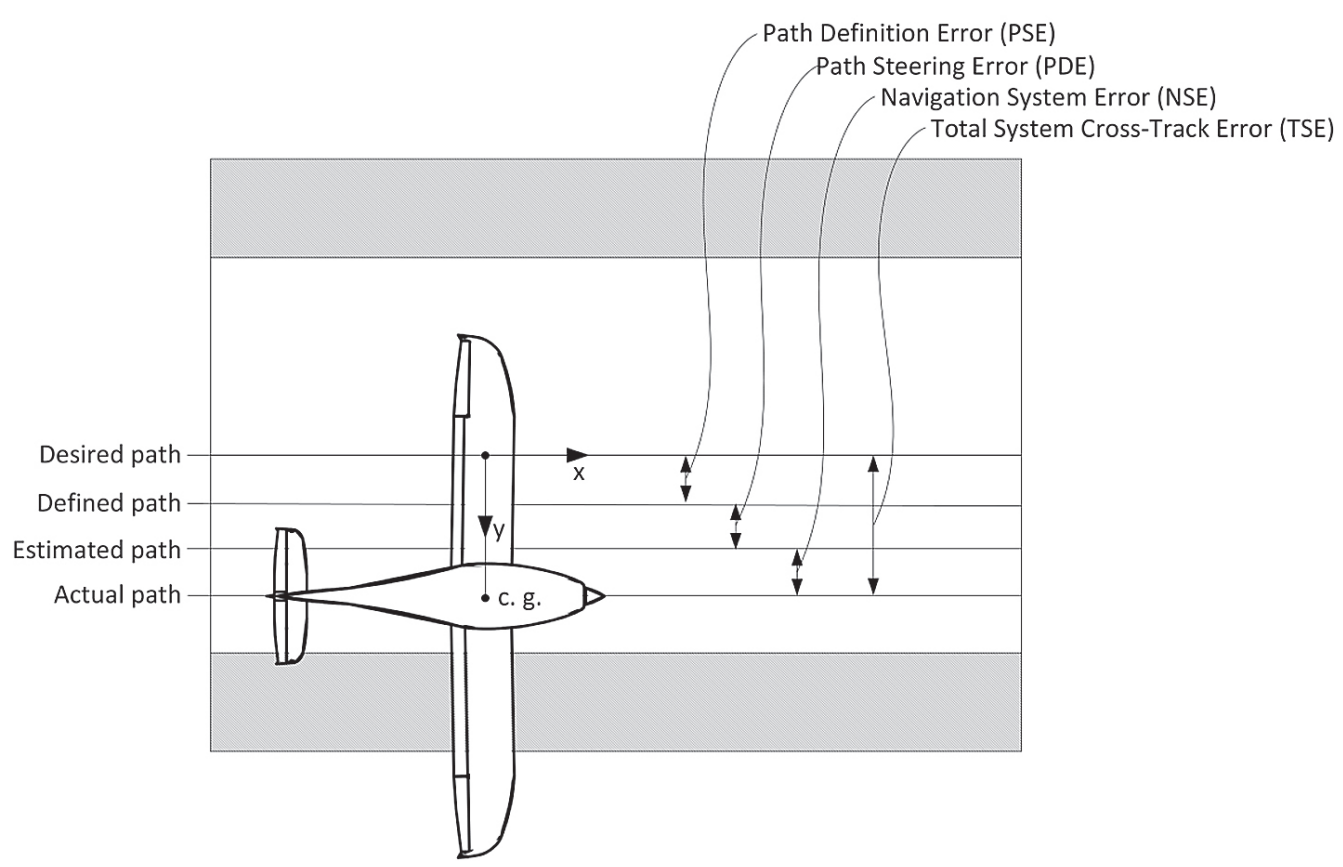

Fig. 2. System lateral error components [Zajdel, 2016] 
The minimum width of the narrowest taxiway coded by a letter " $\mathrm{A}$ " is $7.5 \mathrm{~m}$ [15]. " $\mathrm{A}$ " taxiways are dedicated for aircraft with wingspan smaller than $15 \mathrm{~m}$ and the outer main wheel span smaller than $4.5 \mathrm{~m}$, which covers the aircraft group addressed by the system. The International Civil Aviation Organization (ICAO) standard [12] defines the maximum lateral deviation on that taxiway to $1.5 \mathrm{~m}$ from the centerline. The standard states that the lateral accuracy of the Advanced Surface Movement Guidance and Control System (A-SMGCS) should ensure a $3 \mathrm{~m}$ clearance between aircraft and any other object. To comply with the ICAO guidelines, the total system cross-track error and the longitudinal error should be smaller than $1.5 \mathrm{~m}$.

\subsection{Safety measures}

During taxiing operations the engine operates at low power, therefore the engine parameters (e.g. temperatures) are not likely to exceed the maximum values. However, means for a quick and safe engine cut off and aircraft stop must be foreseen. They include closing the fuel valve, an application of breaks and turning off the electric supply. The first design of the Taxi System will not include the parameters monitoring. During tests, these functions will be performed by the pilot.

\section{SENSORS}

The heading and the ground speed are controlled parameters of the aircraft. The regulator requires their current values to be measured by sensors for the control purposes. The ground speed can be computed from the airspeed indicator, but they are not reliable at low speeds during taxiing. Therefore, Attitude Heading and Reference System (AHRS) must be used. Highly accurate AHRSes are too expensive for the ATCS designed for the General Aviation. Instead, the Microelectromechanical systems (MEMS) AHRSes are taken into consideration. They combine inertial navigation with GPS aiding. Nowadays, constructions offer maximum velocity RMS errors at $0.1 \mathrm{~m} / \mathrm{s}$ and heading errors at $1^{\circ}$ (SBG Systems IG-500N). The computation of a single solution from multiple sources of raw data like: accelerometers, gyroscopes, magnetometers and GPS sensors, usually employ Kalman filtering. The output of the sensors should be sent at a rate higher or equal to $50 \mathrm{~Hz}$ to the effectors, which is considered sufficient for the automatic control of the aircraft in flight.

Actuators position feedback will be used as the controls position information. The brake lever position, the throttle position and the front wheel angle will be computed from equations determining their dependence on the appropriate actuator position. This is influenced also by the form of mechanical connection, the amount of play and stiffness.

\section{CONTROL TECHNIQUES OF THE AUTOMATIC TAXI OF THE AIRCRAFT}

The objective of the LLATCS is the generation of signals for the actuators to move them accordingly, so the aircraft is tracking the desired speed and heading during taxiing. In terms of the control system design and its numerical simulations, the models of the controller, the sensors and the MP-02 Czajka airplane will be developed. The airplane model is a multiple input multiple output (MIMO), 
nonlinear time variant system (NTV). Time variant characteristics are caused by decreasing weight due to fuel consumption . For obvious reasons, the structure of the model will be much different from the generally known models used in flight mechanics [16, 17]. This fact stems from the following two requirements. Firstly, the complex interaction of the landing gear and the ground has to be taken into account during taxiing [18]. The MP-02 Czajka has the composite elastic beam type landing gear. In thoss types of design, where the damping elements - oleo struts - are not present, the process of energy dissipation is a consequence of the tires lateral slips, which in turn is the result of aircrafts vertical movements. Secondly, unlike most of the known mathematical models, the one developed for the purposes of taxiing simulation research is characterized by a different method of aerodynamic forces and moments determination. In particular, this is due to the asymmetric airflow, which results from the transposition of the low ground speed and a much higher wind speed in some cases. Because of that, the determination of the aerodynamics forces and moments coefficients must include any sideslip angle from $0^{\circ}$ to $\pm 180^{\circ}$, which is very unusual during flight. Therefore, the necessary aerodynamic characteristics will be obtained by using both the classical Computational Fluid Dynamics (CFD) methods and the experiments involving the MP-02 airplane model in the water tunnel.

There are several factors that influence the choice of the LLATCS control technique. The aircraft controls can be divided into the throttle and breaks, which affect only the speed and the front wheel and that affects only the heading. In reality, the front wheel deflection has an influence on the speed but for small deflections such a simplification can be assumed. The control algorithm must resolve the problem of throttle and brakes operation which have opposing effects on the acceleration and deceleration. These controls should not be commanded simultaneously. For economical reasons, the minimum use of brakes and the lowest possible fuel consumption is desired. The airplane control algorithm that is going to be certified must comply with the DO-178 standard, which currently assumes that for verification purposes the algorithm must show the deterministic behavior, that is: the computed results, computation time, and resource utilization are predictable at designing stage [19]. This imposes a big challenge for the verification of algorithms which use: stochastic processes, a system identification or learning, e.g. Stochastic Adaptive Control, Model Identification Adaptive Control or Artificial Intelligence Algorithms like Neural Networks and Fuzzy Logic. On the other hand, measures are taken to create methods and tools for validation and verification for those techniques [19, 20].

Considering the feedback linearization technique based on input output approach used in [8], it reduces the nonlinear system control problem to a control problem of a linear system by formulating an input-output mapping function. That function together with the nonlinear plant model represents the linear system. The performance of this method can be degraded by the model uncertainty, which can lead to a closed-loop instability. The method is also sensitive to external disturbances and sensor noise [21]. The classic linear control algorithms involve linearization of the model at chosen operating points. The operating points for taxiing aircraft are determined by its speed, engine RPM, mass, moments of inertia, position of the center of gravity and airport surface condition. Classic design techniques allows of the design of linear controllers such as Linear Quadratic Controller (LQR) or Proportional Integral Derivative 
(PID). The LQR method resolves an optimal control problem. It automates the computation of gains of a state feedback to achieve the optimal control that minimizes the cost function The performance of this method can be lowered when the model is not accurate. It also introduces problems with defining the cost function. When the differences between the linear models for different operating points are significant, the PID gain scheduling technique is used to provide the same level of control quality for all operating conditions. Modification of a classic PID control proved to enhance the control quality of aircraft in flight. The extended version of a PID type controller, named PID ${ }^{2}$, increased the control quality of the attitude of a small aircraft during simulations [22]. The influence of this modification on taxiing control quality has not been examined. Another modification of a PID control is to employ the fuzzy logic method for the computation of gains instead using predefined gain scheduling. This eliminates the undesired effects appearing during the abrupt change of gains caused by transition between different operating points for which the gain scheduling have been computed. In addition, the use of fuzzy logic opens new possibilities for further scientific research on the control algorithm e.g. integration with a Neural Network for self-reorganization of a fuzzy controller [23]. That surpasses a classic PID scheduling control synthesis which nowadays has become an engineering problem with a much worse innovation potential.

\section{CONCLUSIONS}

The published projects of the Automatic Taxi Control Systems are designed for large passenger airplanes and do not take into account the scalability and the versatility of the system. The design of a scalable system which consist of a generic controller part and the airplane specific part will allow to perform the tests on a real general aviation light airplane much faster and cheaper than on an airliner. Additionally, the cited projects miss or just mention accuracy and sensor requirements and treat the actuation of the airplane controls in a simplified manner. To fill this gap, the accuracy requirements were formulated on the basis of existing standards for the Advanced Surface Movement Guidance and Control System published by ICAO. The current affordable MEMS-based AHRS sensors, used for measuring the key airplane parameters (including heading and ground speed), are feasible for the system in the face of formulated accuracy requirements. Moreover, the analysis of the means of control of the airplane during taxiing allowed of the assessment of the possible actuation methods resulting in a choice of three control variables: the front wheel deflection, the brakes position and the engine throttle position. The aircraft model for the Automatic Taxi Control System design must include additional physical effects that are not present during flight: interaction between the tires and the ground, the dissipation of energy by the landing gear and the full range of the sideslip angle influencing aerodynamic forces action. The choice of a control algorithm is influenced by many factors from different fields including the object, the nature of its movement, available controls, economical reasons, future certification challenges and the innovation potential. Taking into consideration all the listed factors, the preliminary choice for the Low Level Automatic Taxi System is the Fuzzy Logic method combined with PID controller. 


\section{REFERENCES}

[1] „Eurocontrol Seven-Years Forecast Flight Movements and Service Units 2016-2022,“ 2016, Eurocontrol.

[2] „Annual Safety Review 2014,“ 2015, European Aviation Safety Agency (EASA), Luxemburg.

[3] Aviation Safety Network, from http://aviation-safety.net/database/record.php?id=19770327-0.

[4] Yeh, M. and Eon, D., „Surface Moving Map Industry Survey,“ 2009, U.S. Department of Transportation, Washington, DC.

[5] Taxibot, 2013, „TaxiBot Taxiboting Concept,“ from http://www.taxibot-international. com/\#! concept/c431.

[6] TugMAXXE, from http://tugmaxxe.com/.

[7] Cheng, V. H. L., 2004, „Surface Operation Automation Research for Airport Tower and Flight Deck Automation," 7th International IEEE Conference on Intelligent Transportation Systems, Washington, DC.

[8] Cheng, V. H. L., Sharma, V. and Foyle, D. C., 2001, „A Study of Aircraft Taxi Performance for Enhancing Airport Surface Traffic Control," IEEE Transactions on Intelligent Transportation Systems, vol. 2, no. 2, pp. 39-54.

[9] Zammit, C. and Zammit-Magnion, D., 2014, „A Control Technique for Automatic Taxi in Fixed Wing Aircraft," 52nd Aerospace Sciences Meeting, AIAA SciTech, (AIAA 2014-1163).

[10] Zammit, C. and Zammit-Magnion, D., 2014, „An enhanced automatic taxi control algorithm for fixed wing aircraft," AIAA Guidance, Navigation, and Control Conference, AIAA SciTech, (AIAA 2014-1300).

[11] European Defence Agency (EDA), 2015, „Remotely Piloted Aircraft Systems - RPAS,” from http://www.eda.europa.eu/what-we-do/activities/activities-search/remotely-piloted-aircraftsystems---rpas.

[12] „Advanced Surface Movement Guidance and Control Systems (A-SMGCS) Manual“, 2004, ICAO.

[13] Graffstein, J., 2009, „Wpływ wybranych zmiennych stanu na dokładność toru lotu samolotu podczas automatycznie wykonywanego manewru,” („An Influence of Selected State Variables on Accuracy of Aircraft Trajectory During Automatically Controlled Manoeuvre"), Prace Instytutu Lotnictwa (Transactions of the Institute of Aviation), no. 202, pp. 51-64.

[14] „Performance-based Navigation (PBN) Manual“, 2008, ICAO, pp. II-A-2-1 - II-A-2-2.

[15] „Aerodrome Design Manual,“ 2005, ICAO.

[16] McLean, D., 1990, Automatic Flight Control Systems, Prentice Hall.

[17] Stevens, B. L. and Lewis, F. L., 1992, Aircraft Control and Simulation, John Wiley \& Sons.

[18] Goraj, Z., Maryniak, J., Paturski, Z. and Złocka, M., 1977, „Stateczność boczna w czasie dobiegu lądującego samolotu sportowego,” („The Lateral Stability Of Sports Aircraft During Landing Run"), Journal of Theoretical and Applied Mechanics, no. 15(4), pp. 501-516, Warsaw.

[19] Bhattacharyya, S., Cofer, D., Musliner, D. J., Mueller, J. and Engstrom, E., 2015, „Certification Considerations for Adaptive Systems," NASA-CR-2015-218702, NASA Langley Research Center, Hampton, Virginia. 
[20] Jacklin, S. A., 2008, „Closing the Certification Gaps in Adaptive Flight Control Software, „ AIAA Guidance, Navigation and Control Conference and Exhibit, Honolulu, Hawaii.

[21] Lee, D., Kim, H. J. and Sastry, S., 2009, „Feedback Linearization vs. Adaptive Sliding Mode Control for a Quadrotor Helicopter," International Journal of Control, Automation, and Systems, no. 7(3), pp. 419-428.

[22] Dołęga, B. and Rogalski, T., 2009, „Control System for Medium-Sized Flying Target,” Aviation, no. 13(1), pp. 11-16,.

[23] Harrison, L., Saunders, P. and Janowitz, J., 1994, „Artificial Intelligence with Applications for Aircraft," FAA.

[24] Cheng, V. H. L., Sweriduk, G., Jack, Y., Andre, A. D. and Foyle, D. C., 2008, „Flight-Deck Automation for Trajectory-Based Surface Operations," AIAA Guidance, Navigation and Control Conference and Exhibit, Honolulu, Hawaii.

[25] Sweriduk, G. D., Cheng, V. H. L., Andre, A. D. and Foyle, D. C., 2007, „Automation Tools for High-Precision Taxiing," 26th Digital Avionics Systems Conference, Dallas, Texas, pp. 1.A.1-1 - 1.A.1-7.

\section{WYBRANE ASPEKTY KONCEPCJI NISKOPOZIOMOWEGO SYSTEMU AUTOMATYCZNEGO STEROWANIA KOLOWANIEM}

\section{Streszczenie}

Kołowanie samolotów załogowych oraz zdalnie sterowanych jest obecnie wykonywane przez pilotów bez wykorzystania systemów automatycznego sterowania kierunkiem i prędkością. W ostatnich latach pojawiło się kilka przesłanek, które uczyniły automatyzację kołowania ważnym wyzwaniem projektowym. Są nimi: obniżona przepustowość portów lotniczych z powodu zwiększającej się liczby samolotów, obniżona wydajność operacji naziemnych w warunkach słabej widzialności, zwiększone obciążenie pilotów oraz kontrolerów ruchu lotniczego i integracja równoczesnych operacji naziemnych samolotów załogowych oraz zdalnie sterowanych. W pracy zaprezentowano wybrane aspekty koncepcji Niskopoziomowego Systemu Automatycznego Sterowania Kołowaniem. W szczególności skupiono się na sposobach sterowania samolotem w trakcie kołowania, wymaganiach odnośnie dokładności systemu i zaproponowano metodę sterowania. Regulator systemu może być zaadaptowany dla różnych samolotów. Mechanizmy wykonawcze oraz ich mechaniczne połączenia z dostępnymi elementami sterującymi samolotem są częścią systemu specyficzną dla danego samolotu i są zaprojektowane dla konkretnego typu - w tym przypadku - lekkiego samolotu general aviation.

Słowa kluczowe: kołowanie, automatyczne kołowanie, system automatycznego sterowania kołowaniem. 